\title{
Dental adhesives and their possible cytotoxic effect on fibroblasts of the oral mucosa - review of the literature
}

\section{Preparaty adhezyjne i ich możliwy cytotoksyczny wpływ na fibroblasty błony śluzowej jamy ustnej - przegląd piśmiennictwa}

\author{
Paula Aleksandra Lasica ${ }^{1}$, Teresa Sierpińska², Dorota Cylwik-Rokicka ${ }^{2}$ \\ ${ }^{1}$ Department of Prosthodontic, Medical University of Bialystok \\ Zakład Protetyki Stomatologicznej, Specjalistyczna Lecznica Stomatologiczna Uniwersytetu Medycznego \\ w Białymstoku \\ 2 Department of Prosthodontic, Medical University of Bialystok \\ Zakład Protetyki Stomatologicznej, Uniwersytet Medyczny w Białymstoku \\ Head: prof. dr hab. n. med. Teresa Sierpińska
}

KEY WORDS:

adhesives, denture adhesives, cytotoxicity of dental adhesives, fibroblasts

\section{Summary}

Introduction. In the era of an ageing society, despite popularization and increased availability of implantoprosthetic treatment, for numerous patients dental adhesives are an essential element of the successful use of dentures. These materials are commonly used to increase retention and stabilisation, as well as improve the quality of use of removable dentures. Adhesives, as generally available, should be biocompatible, and yet reports indicate possible cytotoxic effects on cells of the oral mucosa. It is difficult to identify the specific ingredients responsible for their hazardous properties, due to the fact that the exact composition of these products is restricted information. ${ }^{1}$

Aim of the study. To systematize the available knowledge of the biological properties of denture adhesive products and to present their influence on the cells of the oral mucosa.

Material and methods. A review of the literature using the PubMed and Google Scholar databases was performed.

Results. The analysis of reports in the literature showed a variety of results regarding the studies
HASŁA INDEKSOWE:

preparaty adhezyjne, kleje do protez, cytotoksyczność klejów stomatologicznych, fibroblasty

\section{Streszczenie}

Wstęp. W dobie starzejącego się społeczeństwa, pomimo zwiększonej dostęności do leczenia implantoprotetycznego, preparaty adhezyjne stanowia dla wielu pacjentów niezbędny element uzytkowania protez. Materiaty te, sa stosowa$n e w$ celu zwiększenia retencji, stabilizacji oraz poprawy jakości użytkowania ruchomych protez stomatologicznych. Kleje mocujace, jako ogólnie dostęne, powinny być biokompatybilne, a mimo to doniesienia wskazuja na możliwe cytotoksyczne ich działanie na komórki błony śluzowej jamy ustnej. Trudno jest wskazać składniki odpowiadajace za ich szkodliwe wtaściwości, z powodu zastrzeżonego dokładnego składu tych produktów. ${ }^{1}$

Cel pracy. Celem pracy byto usystematyzowanie dostepnej wiedzy na temat biologicznych wtaściwości protetycznych preparatów adhezyjnych oraz przedstawienie ich wpływu na komórki błony śluzowej jamy ustnej.

Material i metody. Dokonano przegladu piśmiennictwa wykorzystujac baze danych PubMed oraz Google Scholar.

Wyniki. Analiza piśmiennictwa wykazała różnorodność wyników dotyczących badań nad 
on the effects of dental adhesives on fibroblasts of the oral mucosa. Basic assumptions have been presented, and the noticed differences indicated. wplywem stomatologicznych środków adhezyjnych na fibroblasty błony śluzowej jamy ustnej. Przedstawiono podstawowe założenia oraz wyodrębniono zauważone różnice.

\section{Introduction}

The increase in the average age of the population is associated with the fact that the number of patients using dental prostheses tends to increase. It is estimated that by 2020 the number of users of complete dentures will have increased to 61 million in the USA alone. ${ }^{2}$ Therefore, there emerged a need to offer products that would improve the quality of their everyday use. The first reports on adhesive materials were published in 1935 by the American Dental Association, which classified them as non-medical materials. However, these products were used as early as at the end of the 18th century. ${ }^{3-5}$ At that time, they were in the form of a plant mixture absorbing saliva moisture, increasing its volume and improving the contact between the prosthesis and the mucosa. Over time, the products were developed to improve their physical properties. The ideal denture adhesive described in the literature should be non-toxic, non-irritating, biocompatible, inhibiting the reproduction of fungi and bacteria, tasteless and odourless, as well as easy to use. ${ }^{6,7}$ In 1970, an adhesive with the addition of calcium salts was created, and in 1980, zinc became a new component. Currently, due to emerging reports of the harmful effects of zinc, it has been removed from the original composition, and the companies advertise their products as "zinc-free materials". It is already known that excessive zinc absorption into the body causes hypocupremia (copper deficiency) leading to neurological disorders and bone marrow suppression. ${ }^{2,8,9}$ Attempts to use antibacterial

\section{Wstęp}

Wraz ze wzrostem średniej wieku społeczeństwa, liczba pacjentów użytkujących protezy stomatologiczne ma tendencję wzrostową. Szacowano, że do 2020 roku liczba użytkujących protezy całkowite, tylko w USA wzrośnie do 61 milionów. ${ }^{2} \mathrm{~W}$ związku $\mathrm{z}$ tym pojawiła się potrzeba zaproponowania produktów umożliwiających poprawę jakości codziennego ich stosowania. Pierwsze doniesienia o materiałach adhezyjnych zostały opublikowane w 1935 r. przez American Dental Association, które zaliczyło je do materiałów niemedycznych. Jednak produkty te stosowane były już pod koniec XVIII wieku. ${ }^{3-5}$ Miały one wtedy postać roślinnej mieszanki pochłaniającej wilgoć śliny, zwiększającej swoją objętość oraz poprawiającej kontakt protezy ze śluzówką. Z czasem zaczęto udoskonalać produkty celem poprawy ich właściwości fizycznych. Klej do protez zębowych opisywany w literaturze, powinien być nietoksyczny, niedrażniający, biokompatybilny, hamujący namnażanie grzybów i bakterii, bez smaku i zapachu oraz łatwy w użyciu. ${ }^{6,7} \mathrm{~W} 1970$ r. powstał klej z dodatkiem soli wapnia, a w 1980 r. nowym składnikiem stał się cynk. Obecnie, ze względu na pojawiające się doniesienia o szkodliwym działaniu cynku, został on wycofany z oryginalnego składu, a firmy reklamują swoje produkty jako „zinc-free materials”. Nadmierne wchłanianie cynku do organizmu powoduje hypokupremię (niedobór miedzi) prowadzącą do zaburzeń neurologicznych a także do zahamowania czynności szpiku kostnego. ${ }^{2,8,9}$ Istotne są próby stosowania dodatków przeciwbakteryjnych oraz przeciwgrzybiczych, które mogłyby być 
and antifungal additives, that could become very popular among patients susceptible to candidiasis, are important. In addition, there have been attempts to create materials that prevent food and dental plaque retention, which would enable longer use of the denture without changing the adhesive. ${ }^{2}$ According to research, approximately $6.9 \%$ of denture users apply adhesives systematically, and approximately $32.9 \%$ have tried them at least once. ${ }^{10}$ According to the ISO (International Organization for Standardization) standards, these products are widely available over the counter, but so far no quality standards have been defined. Although there are many products that improve the retention of removable prosthetic restorations on the market, new ones are still being launched. According to the ISO, dental adhesive products are categorized as "glues" (as powders, creams, sheets or tapes), where the component is a water-soluble polymer, and "pads" of an anhydrous paste. ${ }^{11}$ Among the aforementioned products, the most popular and effective is the one in the form of a cream. ${ }^{12}$ These products consist of three main components: a component responsible for adhesion, an antimicrobial agent and fillers. The ingredients responsible for adhesion are, among others, gum karaya, gelatin, pectins, carboxymethyl cellulose and sodium carboxymethyl cellulose. Antimicrobial agents that also prevent Candida albicans infections are sodium borate, sodium tetraborate, hexachlorophene and propyl hydroxybenzoate. The fillers are mainly magnesium oxide. However, as previously mentioned, the exact composition of these materials is treated as a commercial secret and differs between individual products. ${ }^{13}$

The universal access to adhesives prompted many scientists to analyse their influence on the oral mucosa, and thus on the development and course of denture-related stomatitis. According to numerous studies, adhesives may stosowane u pacjentów podatnych na kandydozę. Ponadto, podejmowane są próby stworzenia materiałów zapobiegających retencji pokarmów oraz płytki nazębnej, co umożliwiłoby dłuższe użytkowanie protezy bez wymiany środka adhezyjnego. ${ }^{2}$ Jak podają badania, około 6,9\% użytkujących protezy stomatologicznie stosuje kleje adhezyjne systematycznie, a około $32,9 \%$ przynajmniej raz spróbowało ich użycia. ${ }^{10}$ Zgodnie z normami ISO (Międzynarodowa Organizacja Normalizacyjna), produkty te są powszechnie dostępne bez recepty, jednak do tej pory nie określono ich norm jakościowych. Mimo że na rynku dostępnych jest wiele produktów poprawiających retencję ruchomych uzupełnień protetycznych, to wciąż pojawiają się nowe. ISO dzieli stomatologiczne preparaty adhezyjne na formę ,kleju” (jako proszki, kremy, arkusze czy taśmy), gdzie składnikiem jest polimer rozpuszczalny w wodzie oraz formę ,wkładki”, w postaci bezwodnej pasty. ${ }^{11}$ Wśród wymienionych najbardziej popularną oraz efektywną jest forma kremu. ${ }^{12}$ Preparaty te składają się z 3 głównych komponentów: odpowiedzialnego za adhezję, środka przeciwdrobnoustrojowego oraz wypełniaczy. Składnikami odpowiedzialnymi za adhezję są między innymi guma karaya, żelatyna, pektyny, hydroksymetyloceluloza oraz sól sodowa karboksymetylocelulozy. Środkami przeciw drobnoustrojom, których zadaniem jest również zapobieganie zakażeniom Candida albicans są boran sodowy, czteroboran sodu, heksachlorofen czy hydroksybenzoesan propylu. Do wypełniaczy zaliczany jest głównie tlenek magnezu. Jednak jak wcześniej już wspomniano, dokładne składy tych materiałów chronione są tajemnicą producenta i różnią się między poszczególnymi produktami. $^{13}$

Powszechny dostęp do środków adhezyjnych skłonił wielu badaczy do analizy ich wpływu na błonę śluzową jamy ustnej, a tym samym na rozwój i przebieg stomatopatii protetycznych. Jak podają liczne badania, kleje mogą mieć cytotoksyczny wpływ na komórki błony śluzowej jamy 
have a cytotoxic effect on the cells of the oral mucosa. Therefore, the question arises whether adhesive materials should be offered by dentists only to patients using immediate dentures, with significant resorption of the alveolar processes, disorders of neuromuscular control (Parkinson's disease, stroke), xerostomia or significant defects of the facial skeleton caused by cancer or trauma. ${ }^{2,12,14}$ It should also be noted that patients who constantly use materials that improve the retention of their prosthetic restorations without the supervision of a doctor, are often convinced of the mediocre quality of the prosthetic treatment. On the other hand, physically active patients often use them to improve their own mental comfort, because, according to studies, the strength of maintaining a complete denture with the use of an adhesive is more than twice as high. ${ }^{15}$ Moreover, numerous reports show that the application of adhesive agents significantly improves the use of complete dentures in patients with salivary secretory disorders, appearing between the ages of 50 and 60 years. ${ }^{16}$ However, due to xerostomia, these agents can cause allergic reactions and bacterial contamination. ${ }^{17}$ Additionally, they have also been confirmed to significantly impair taste perception. ${ }^{18}$ Also in the case of diabetic patients, an increase in the level of Candida albicans ${ }^{19}$, which is responsible for candidosis, the most common disease of the oral cavity, was found. ${ }^{20}$

\section{Fibroblasts}

Fibroblasts, as the most numerous cells of the lamina propria of the oral mucosa, play a special role in inflammation and periodontal regeneration. ${ }^{21,22}$ Healing of the mucosa, similarly to healing of the skin, takes place through haemostasis, inflammation, cell proliferation and reconstruction of the collagen matrix. It is well known that the oral mucosa heals much faster than the skin, ustnej. W związku z tym, pojawia się pytanie, czy materiały adhezyjne nie powinny być zalecane przez lekarzy dentystów jedynie pacjentom użytkującym protezy natychmiastowe, ze znaczą resorpcją wyrostków zębodołowych, zaburzeniami kontroli nerwowomięśniowej (choroba Parkinsona, udar mózgu), kserostomią czy znacznymi defektami twarzoczaszki wywołanymi chorobą nowotworową lub urazem. 2,12,14 Należy również zaznaczyć, że pacjenci stale użytkujący materiały poprawiające retencję uzupełnień protetycznych bez kontroli lekarza, często są przeświadczeni o złej jakości leczenia protetycznego. Natomiast pacjenci aktywni fizycznie, często je wykorzystują celem poprawy własnego komfortu psychicznego, ponieważ jak podają badania, siła utrzymania protezy całkowitej na podłożu po zastosowaniu kleju, jest ponad dwukrotnie większa. ${ }^{15}$ Ponadto liczne badania wskazują, że stosowanie środków adhezyjnych znacznie poprawia użytkowanie protez całkowitych u pacjentów z zaburzeniami sekrecji śliny, pojawiającymi się między 50 a 60 rokiem życia. ${ }^{16}$ Jednak, ze względu na suchość w jamie ustnej, mogą one wywoływać reakcje alergiczne oraz kontaminacje bakteryjne. ${ }^{17}$ Dodatkowo potwierdzono, że środki te znacznie zaburzają odczuwanie smaków. ${ }^{18}$ Natomiast w przypadku pacjentów chorych na cukrzycę, stwierdzono wzrost poziomu grzybów z rodzaju Candida albicans, ${ }^{19}$ który odpowiada za najczęstszą jednostkę chorobową jamy ustnej- grzybicę. ${ }^{20}$

\section{Fibroblasty}

Fibroblasty jako najliczniejsze komórki blaszki właściwej błony śluzowej jamy ustnej, odgrywają szczególną rolę w stanach zapalnych oraz regeneracji przyzębia. ${ }^{21,22}$ Gojenie błony śluzowej, podobnie jak skóry, przebiega poprzez hemostazę, stan zapalny, proliferację komórek oraz przebudowę macierzy kolagenowej. Powszechnie wiadomo, że błona śluzowa jamy ustnej goi się znacznie szybciej niż skóra, pozostawiając nieznaczne blizny. $\mathrm{Na}$ 
leaving slight scaring. Based on numerous studies, it is known to be associated with a lower number of inflammatory cells, lower production of proinflammatory cytokines, neutrophils, macrophages, T cells, IL-6 and, above all, a specific reaction of fibroblasts, which, with the participation of growth factors (PDGF - platelet-derived growth factor, FGF- fibroblast growth factor, TGF$\beta$-transforming growth factor beta), play a key role in the healing of wounds in the oral mucosa. Fibroblasts are considered to be young, metabolically efficient cells that, using the mechanism of movement orientation, move to the sites of tissue injury. ${ }^{23}$ Due to their significant proliferation, fibroblasts take part in repair processes: they provide a fresh wound with tension force, secrete cytokines into the wound matrix, increase the production of MMP-3 (metalloproteinase) and induce the proliferation of collagen fibres. The frequency of divisions increases under the influence of FGF, the concentration of which increases significantly during the healing of connective tissue. ${ }^{23}$ It should also be emphasised that numerous researchers indicate a significant similarity of the phenotype of oral mucosa fibroblasts to foetal fibroblasts, which may be responsible for faster healing of irritated areas in young patients compared to geriatric patients. ${ }^{24-27}$

Fibroblasts of the oral mucosa are exposed to adhesive components when ulcerative lesions are present. ${ }^{1}$ An ulcer is an open wound of the mucosa whose damage, unlike in the case of erosions, exceeds its basal layer. ${ }^{28}$ And yet, in everyday prosthetic practice, patients very often report pain associated with mechanical irritation or damage to the mucosa related to the use of removable prosthetic restorations. Therefore, it is necessary to analyse and thoroughly assess the advantages and disadvantages of such common and popular dental materials. podstawie licznych badań, wiadomo iż związane jest to z mniejszą liczbą komórek zapalnych, mniejszą produkcją cytokin prozapalnych, neutrofili, makrofagów, komórek T, IL-6 a przede wszystkim specyficzną reakcją fibroblastów, które przy udziale czynników wzrostu (PDGFpłytkopochodny czynnik wzrostu, FGF- czynnik wzrostu fibroblastów, TGF- $\beta$ - transformujący czynnik wzrostu beta), pełnią kluczową rolę $\mathrm{w}$ gojeniu ran błony śluzowej jamy ustnej. Fibroblasty uważane są za młode, sprawne metabolicznie komórki, które wykorzystując mechanizm ukierunkowania ruchu, przesuwają się ku miejscom uszkodzenia tkanek. ${ }^{23}$ Dzięki znacznej proliferacji, fibroblasty biorą udział w procesach naprawczych: dostarczają świeżej ranie siłę rozciągającą, wydzielają cytokiny do macierzy rany, zwiększają produkcję MMP-3 (metaloproteinazy) oraz indukują proliferację włókien kolagenowych. Częstość podziałów zwiększa się pod wpływem FGF, którego stężenie znacznie się zwiększa w czasie gojenia tkanki łącznej. ${ }^{23}$ Należy również podkreślić, że wielu badaczy wskazuje na znaczne podobieństwo fenotypu fibroblastów błony śluzowej jamy ustnej do fibroblastów płodu, co może wskazywać na przyczynę szybszego gojenia podrażnień u młodych pacjentów w stosunku do pacjentów geriatrycznych. ${ }^{24-27}$

Fibroblasty błony śluzowej jamy ustnej narażone są na składniki klejów adhezyjnych, kiedy występują na niej zmiany owrzodzeniowe. ${ }^{1}$ Owrzodzenie jest otwartą raną błony śluzowej, której uszkodzenie w przeciwieństwie do nadżerki, przekracza jej warstwę podstawną. ${ }^{28}$ A przecież w codziennej praktyce protetycznej bardzo często pacjenci zgłaszają się z powodu dolegliwości bólowych spowodowanych mechanicznym podrażnieniem lub uszkodzeniem błony śluzowej, związanym z użytkowaniem ruchomych uzupełnień protetycznych. Dlatego też, konieczna stała się ocena korzyści jak i skutków ubocznych stosowania tak powszechnych i popularnych środków 


\section{Aim of the study}

The aim of the literature review was to systematize the available knowledge of the biological properties of adhesive products, and to present their influence on the cells of the oral mucosa.

\section{Material and methods}

The literature review was performed using the PubMed and Google Scholar databases by introducing the following keywords: "Denture adhesives", "Dental adhesives". A total of 28 papers meeting the assumed criteria were qualified for the analysis. After narrowing the topic and adding the keywords: "Cytotoxicity of denture adhesives", "Fibroblasts", "Oral fibroblasts", 14 studies were selected. Then, papers published before 2005 were rejected, and 7 papers on cytotoxicity from the last 15 years qualified for analysis.

\section{Results}

Most of the research concerning dental adhesives has focused on their physical properties and on improving the quality of use of removable dentures. Few concerned the cytotoxic or irritant properties. Therefore, as a result of the emerging reports on the negative impact of commonly used adhesive materials on the health of patients, the attention of the researchers started to focus on their influence on the individual elements of the oral mucosa.

In the analysed literature, the researchers mainly focused on oral mucosa fibroblasts, often comparing the results with the L929 cell line. L929 is a continuous line of murine fibroblasts (connective tissue proper cells) displaying specificity for the interface (adherent cells). L929 line cells, used for many years in screening trials, are normally applied to adhezyjnych przez użytkowników ruchomych uzupełnień protetycznych.

\section{Cel pracy}

Celem przeglądu piśmiennictwa jest usystematyzowanie dostępnej wiedzy na temat biologicznych właściwości i wpływu preparatów adhezyjnych na komórki błony śluzowej jamy ustnej.

\section{Material i metody}

Dokonano przeglądu piśmiennictwa wykorzystując bazę danych PubMed oraz Google Scholar używając kluczowych słów „Denture adhesives”, „Dental adhesives”. Do analizy zakwalifikowano w sumie 28 prac, spelniających założone kryteria. Po zawężeniu tematyki i dodaniu haseł „Cytotoxicity of denture adhesives”, „Fibroblasts”, „Oral fibroblasts” wyodrębniono 14 prac. Starsze niż z roku 2005 odrzucono, do analizy pozostało 7 artykułów dotyczących cytotoksyczności z ostatnich 15 lat.

\section{Wyniki}

Większość badań dotyczących klejów stomatologicznych skupiała się na ich właściwościach fizycznych oraz poprawie jakości użytkowania protez ruchomych. Niewiele z nich dotyczyło właściwości cytotoksycznych czy podrażniających. Dlatego też, w związku z pojawiającymi się doniesieniami o negatywnym wpływie powszechnie stosowanych materiałów adhezyjnych na zdrowie pacjentów, zaczęto doszukiwać się ich wpływu na poszczególne elementy błony śluzowej jamy ustnej.

W dostępnej literaturze, badacze skupiali się głównie na fibroblastach błony śluzowej jamy ustnej, często porównując wyniki z linią komórkową L929. Jest to ciągła linia mysich fibroblastów (komórek tkanki łącznej właściwej), wykazujących specyficzność względem 
evaluate new drugs as well as the cytotoxicity of biomaterials in dentistry. ${ }^{1,29}$

Oral mucosa fibroblasts were obtained from, among other places, gingival pockets and during surgical procedures. ${ }^{1,30}$ Selected patients did not suffer from chronic diseases, did not take medications, and did not experience gingival bleeding. ${ }^{30}$ The agar diffusion test, XTT test, CVDE test, gentian test, flow cytometry apoptosis detection assay, ELISA and MTT assay (the most frequently used test for the analysis of cell metabolic activity) were used for the research. ${ }^{1,8,14,30,31}$ In addition, SEM (scanning electron microscopy) and CLSM (confocal microscopy) were used to study the cells. $^{8,31}$

Based on seven publications, six of them indicated some degree of cytotoxicity, while one study showed no cytotoxicity of the adhesive materials.

In $2005 \mathrm{Al}$ et al., after testing five available adhesive materials, demonstrated that only one of the agents caused a slight cytotoxic effect in the MTT assay and agar test. One product also induced cell lysis. The others may only indicate the possibility of causing inflammation. However, the authors emphasised that the cytotoxic potential increased with duration of exposure, which could have influenced the study results. $A l$, citing research from the $80 \mathrm{~s}$ and 90 s, did not exclude the possibility that the bacterial contamination of adhesives may have a detrimental effect on the oral mucosa. They also emphasised that frequent replacement of the adhesive material should eliminate possible cytotoxic effects. ${ }^{7}$

In 2011, de Gomes et al., showed an increase in cytotoxicity and a growth inhibition of human and murine fibroblasts from the L929 line, depending on the concentration of the product. In addition, a reduction in the volume of the cytoplasm, contraction of the cytoskeleton, cell rounding, and other cellular disturbances took place. Most of powierzchni międzyfazowej (komórki adherentne). Komórki linii L929 wykorzystywane przez wiele lat $\mathrm{w}$ badaniach screeningowych, są standardowo używane do oceny nowych leków, a także cytotoksyczności biomateriałów W stomatologii. ${ }^{1,29}$

Fibroblasty błony śluzowej jamy ustnej pozyskiwano między innymi z kieszonek dziąsłowych oraz podczas zabiegów chirurgicznych. ${ }^{1 \text {, }}$ 30 Wybierano pacjentów pozbawionych chorób przewlekłych, nie przyjmujących leków, bez krwawienia dziąseł. ${ }^{30}$ Do badań wykorzystywano dyfuzyjny test agarowy, test XTT, CVDE, test gencjanowy, test apoptozy metodą cytometrii przepływowej, test ELISA oraz test MTT (najczęściej stosowany test do analizy aktywności metabolicznej komórki). ${ }^{1,8,14,30,31}$ Ponadto do obserwacji komórek wykorzystywano między innymi SEM (skaningowa mikroskopia elektronowa) oraz CLSM (mikroskopia konfokalna). $.8,31$

Na podstawie 7 publikacji, $6 \mathrm{z}$ nich wskazało na pewien stopień cytotoksyczności, tylko 1 badanie wykazało brak cytotoksyczności materiałów adhezyjnych.

W 2005 Al i wsp. po przebadaniu 5 dostępnych materiałów adhezyjnych wykazali, że jedynie 1 ze środków wywołał nieznaczny efekty cytotoksyczny w badaniu MTT i teście agarowym. Jeden z produktów wywołał również lizę komórek. Pozostałe mogą jedynie wskazywać na możliwość wywołania stanu zapalnego. Podkreślono jednak, że potencjał cytotoksyczny zwiększał się wraz ze wzrostem czasu ekspozycji, co mogło wpłynąć na wyniki badania. Autorzy powołując się na badania z lat 80 i 90, nie wykluczyli, że to kontaminacja bakteryjna środków adhezyjnych może mieć szkodliwy wpływ na błonę śluzową jamy ustnej. Podkreślili również, że częsta wymiana materiału adhezyjnego powinna zniwelować możliwe efekty cytotoksyczne. ${ }^{7}$

W 2011 de Gomes i wsp. wykazali wzrost cytotoksyczności oraz zahamowanie wzrostu fibroblastów ludzkich i mysich z linii L929, 
the tested samples showed some level of toxicity, depending on the concentration and time of exposure to the material. However, the researchers emphasised that the dynamic environment of the oral cavity, fluctuations in saliva level, temperature and $\mathrm{pH}$ could have influenced the obtained results. ${ }^{8}$

In 2012, Chen et al., comparing human fibroblasts with L929 cells demonstrated no cytotoxic effect on murine fibroblasts. This indicates significant differences between human cells and L929 cells, which may affect the reliability of the study. The researchers concluded that the adhesives caused a slight and moderate cytotoxic effect on the fibroblasts of the oral mucosa. Moreover, they implicated formaldehyde as a component showing a high level of cytotoxicity. They also emphasised the effect of the concentration of the material: the diluted adhesive produced a cytotoxic effect in only one out of three tested samples, while the undiluted product in all three. ${ }^{1}$

In 2014, Lee et al., in their research indicated that all the adhesive materials they investigated showed a significant cytotoxic effect on the tested fibroblasts. An interesting result was that certain materials induced a much greater apoptosis of cells, and that the released silica may be the responsible component. Lee also stressed the importance of the concentration of the material and exposure time. In addition, studies have shown a reduction in cell viability, the initiation of apoptosis and necrosis of other mucosal cells, a reduction in the volume of the cytoplasm and contraction of the actin cytoskeleton. ${ }^{31}$

In turn, in 2020, Yamada et al. used the adhesive material of the same $10 \%$ concentration and exposure time of 24 hours for all samples. They emphasised that the $\mathrm{pH}$ had no effect on the results of the tested samples. However, they clearly indicated that they used a higher concentration of materials to reproduce the conditions in the oral cavity zależne od stężenia produktu. Ponadto występowało zmniejszenie objętości cytoplazmy, kurczenie się cytoszkieletu, zaokrąglanie komórek oraz inne zakłócenia komórkowe. Większość przebadanych przez niego próbek wskazywała pewien poziom toksyczności, zależny od stężenia i czasu ekspozycji na materiał. Jednak badacze podkreślili, że dynamiczne środowisko jamy ustnej, fluktuacje poziomu śliny, temperatura oraz pH mogły wpłynąć na uzyskane wyniki. ${ }^{8}$

W 2012 Chen i wsp. porównując ludzkie fibroblasty z komórkami L929, wykazali brak efektu cytotoksycznego na fibroblasty myszy. Wskazuje to na znaczne różnice komórek ludzkich oraz komórek L929, co może wpływać na wiarygodność badań. Autorzy podali w wynikach, że kleje wywołały lekki i umiarkowany efekt cytotoksyczny na fibroblasty błony śluzowej jamy ustnej. Ponadto wskazano na formaldehyd jako składnik wykazujący wysoki poziom cytotoksyczności. Podkreślono również wpływ stężenia materiału: rozcieńczony klej adhezyjny wywołał efekt cytotoksyczny jedynie w 1 na 3 badane próbki, zaś nierozcieńczony we wszystkich trzech. ${ }^{1}$

W 2014 Lee i wsp.w swoich badaniach wskazali, że wszystkie użyte przez niego materiały adhezyjne wykazały znaczący efekt cytotoksyczny na badane fibroblasty. Ciekawym wynikiem było wykazanie, że pewne materiały wywołują znacznie większą apoptozę komórek, a składnikiem, który może za nią odpowiadać jest uwalniająca się krzemionka. Badacze również podkreślili znaczenie stężenia i czasu ekspozycji materiału. Ponadto badania przedstawiły obniżenie żywotności komórek, zainicjowanie apoptozy i nekrozy także innych komórek błony śluzowej, zmniejszenie objętości cytoplazmy oraz skurczenie aktynowego cytoszkieletu. ${ }^{31}$

Z kolei Yamada i wsp. w 2020r. do wszystkich próbek wykorzystali materiał adhezyjny o jednakowym $10 \%$ stężeniu i czasie ekspozycji 24 godzin. Podkreślili, że pH nie miało wpływu na wyniki badanych próbek. Jednak 
of geriatric patients associated with less daily saliva production. Based on these results, it can be concluded that the level of cytotoxicity of adhesive materials depends on individual conditions, the material used, as well as the concentration and time of exposure. ${ }^{14}$

Lopez-Garcia et al. also conducted their research in 2020. After 24, 48 and 72-hour incubation period, the researchers indicated changes in the $\mathrm{pH}$ of the medium, an increase in the production of reactive oxygen species, a change in cell morphology and the induction of apoptosis and necrosis of cells. They emphasised that different levels of cytotoxicity of the tested adhesive materials depend primarily on their composition. The researchers focused on assessing zinc as a toxic component, but strongly emphasised that there was no evidence that adhesives containing zinc induced apoptosis and necrosis of cells. They suggested that in order to confirm this hypothesis it was necessary to retest the products after eliminating zinc salts from their composition. ${ }^{13}$

In 2017, Soares et al. presented their results contrasting with the aforementioned ones. They used mucosa samples from a 30- and 62-year-old donor. In their study, they emphasised the greater sensitivity of older cells to unfavourable environmental conditions, weaker mitochondrial activity, production of reactive oxygen and repair capabilities. The researchers demonstrated that none of the samples had a cytotoxic effect, but indicated a clear effect on the level of cytokines and growth factor. In addition, they demonstrated that the results for the older donor samples were worse. This suggests the necessity to use samples from older donors when testing products intended for geriatric patients. However, Soares did not reject the possibility that individual factors, not age, could have influenced the results of the study. ${ }^{30}$ wskazali wyraźnie, że zastosowano wyższe stężenie materiałów, aby odwzorować warunki panujące w jamie ustnej pacjentów geriatrycznych związane z mniejszą dobową ilością wydzielanej śliny. Na podstawie wyników można wnioskować, że poziom cytotoksyczności materiałów adhezyjnych zależny jest od indywidualnych warunków, użytego materiału a także stężenia i czasu ekspozycji. ${ }^{14}$

Również w 2020 r. swoje badania przeprowadzili Lopez-Garcia i wsp. Po 24, 48 oraz 72-godzinnej inkubacji, badacze wskazali na zmiany $\mathrm{pH}$ podłoża, wzrost produkcji reaktywnych form tlenu, zmianę morfologii komórek oraz indukcję apoptozy i nekrozy komórek. Podkreślili, że odmienny poziom cytotoksyczności przebadanych materiałów adhezyjnych zależny jest przede wszystkim od ich składu. Badacze skupili się na ocenie cynku jako składnika toksycznego, jednak uważają, że nie ma dowodów na to, aby to kleje zwierające cynk wywoływały apoptozę i nekrozę komórek. Zasugerowano, że dla potwierdzenia tej hipotezy konieczne jest ponowne przebadanie produktów eliminując sole cynku z ich składu. ${ }^{13}$

W 2017 w kontraście do poprzednich swoje wyniki przedstawili Soares i wsp. Wykorzystali próbki błony śluzowej od dawcy 30 oraz 62-letniego. W pracy podkreślili większą wrażliwość starszych komórek na niekorzystne warunki środowiska, słabszą aktywność mitochondrialną, produkcję reaktywnego tlenu i możliwości naprawcze. Autorzy wykazali brak efektu cytotoksycznego wszystkich próbek, jednak wskazali wyraźny wpływ na poziom cytokin oraz czynnika wzrostu. Ponadto wykazano gorsze wyniki badań próbek starszego dawcy. Sugeruje to na konieczność wykorzystywania próbek od starszych dawców w przypadku badania środków dedykowanych pacjentom geriatrycznym. Jednak autorzy pracy nie odrzuca możliwości, że to czynniki indywidualne, a nie wiek mogły wpłynąć na wyniki badań. ${ }^{30}$ 


\section{Discussion}

The lack of standardized, identical methods of conducting experiments results in big problems of interpretation. In different studies conducted in several countries, various adhesive products with different compositions were used: in South Korea Lee et al. tested Polident, Protefix, Staydent and Denfix-A. ${ }^{31}$ In Brazil, the team led by Soares tested Corega Ultra (cream), Corega powder and Fixodent Original. ${ }^{30}$ In Japan, Yamada et al. used Faston, Poligrip Powder, New Poligrip Free, Tafugurippu Kurimu, Polident Adhesive and Tafugurippu Tomei $^{14}$ for their tests. In Portugal, Gomes et al. used Corega cream, Protefix cream, Steradent cream, Novafix cream, Polident cream, Kukident cream, Aderyn powder, Corega powder, Protefix powder and Corega pad. ${ }^{8}$ In Greece, $A l$ et al. tested Blend-a-dent Super Haftcreme Extra stark, Fittydent superadesivo, Protefix adhesive cream extra-strong, Protefix adhesive powder extra-strong and Protefix adhesive cushions for upper, lower denture. ${ }^{7}$ In Spain, Lopez-Garcia et al. used Poligrip Flavor Free Fixative Cream, Fixodent Pro Duo Protection, Novafix cream, FittyDent, Polident Total Action and Fixodent Pro Plus Duo Protection..$^{13}$ In turn, in China, Chen et al. used Polident cream, Protefix cream and Protefix powder for their tests. ${ }^{1}$

Fibroblasts also originated from a variety of sources: L929 (line of murine fibroblasts) ${ }^{1,8}$ and fibroblasts collected from gingival pockets, obtained from healthy gingiva during extractions for orthodontic reasons ${ }^{1}$ and other surgical procedures. ${ }^{30}$

In seven qualified studies, various research methods were used:

1. The MTT assay was used in five studies. ${ }^{1,7,8,13,31}$ It is most often used to analyse cell metabolic activity and cytotoxicity of new drugs. The MTT assay uses the ability

\section{Dyskusja}

Brak wystandaryzowanych, jednakowych metod prowadzenia doświadczeń sprawia duże problemy interpretacyjne. W poszczególnych badaniach prowadzonych $w$ innych krajach zastosowano różne preparaty adhezyjne o niejednakowym składzie: w Korei Południowej Lee i wsp. przebadali Polident, Protefix, Staydent oraz Denfix-A. ${ }^{31} \mathrm{~W}$ Brazylii zespół kierowany przez Soaresa i wsp. testował Corega Ultra (cream), Corega powder i Fixodent Original. ${ }^{30} \mathrm{~W}$ Japonii Yamada i wsp. do prób użyli Faston, Poligrip Powder, New Poligrip Free, Tafugurippu Kurimu, Polident Adhesive, Tafugurippu Tomei. ${ }^{14} \mathrm{~W}$ Portugalii Gomes i wsp. wykorzystali Corega cream, Protefix cream, Steradent cream, Novafix cream, Polident cream, Kukident cream, Aderyn powder, Corega powder, Protefix powder oraz Corega pad. ${ }^{8}$ W Grecji $A l$ i wsp. zbadali Blend-a-dent Super Haftcreme Extra stark, Fittydent super-adesivo, Protefix adhesive cream extra-strong, Protefix adhesive powder extra-strong, Protefix adhesive cushions- upper, lower denture. ${ }^{7}$ W Hiszpanii Lopez-Garcia i wsp. wykorzystali Poligrip Flavour Free Fixative Cream, Fixodent Pro Duo Protection, Novafix cream, FittyDent, Polident Total Action oraz Fixodent Pro Plus Duo Protection. ${ }^{13}$ Natomiast w Chinach Chen i wsp. użyli do testów Polident cream, Protefix cream i Protefix powder. ${ }^{1}$

Fibroblasty również pochodziły $\mathrm{z}$ różnych źródeł: L929 (linia mysich fibroblastów) ${ }^{1,8}$ oraz pobierane z kieszonek dziąsłowych, pozyskiwane ze zdrowego dziąsła przy ekstrakcjach ze wskazań ortodontycznych ${ }^{1} \mathrm{i}$ innych zabiegach chirurgicznych. ${ }^{30}$

W 7 zakwalifikowanych pracach wykorzystano różne metody badawcze:

1. Test MTT wykorzystano w 5 badaniach. 1,7,8,13,31 Jest on najczęściej stosowany do analizy aktywności metabolicznej 
of the enzyme called a mitochondrial dehydrogenase to convert a water-soluble tetrazole salt (3-(4,5-dimethylthiazol-2-yl)-2,5-diphenyltetrazolium bromide) into an insoluble formazan. After dissolving formazan crystals in dimethyl sulfoxide or isopropanol, a coloured solution is formed, the colour intensity of which is measured using a spectrophotometer in the wavelength range of 492-570 nm. The amount of coloured reduced MTT is proportional to the oxidative activity of the mitochondria in the cell and under strictly determined experimental conditions to the viable cell count in the population. However, according to new research, this test may prove to be inappropriate for assessing the viable cell count, which may also affect the interpretation of the results. ${ }^{32}$

2. The XTT assay was used in one study. ${ }^{30}$ This assay, similar to the MTT one, detects mitochondrial metabolism, but it is more sensitive than the MTT assay. ${ }^{30}$

3. The flow cytometry (FCM) assay consisting in the retention of dyes was used in one stu$\mathrm{dy}^{31}$ to analyse the viable, apoptotic and necrotic cell count. ${ }^{33}$

4. The ELISA (enzyme-linked immunosorbent assay) used in one study was applied to assess the level of released IL- 6 and bFGF. ${ }^{30}$ It is one of the most popular tests used in medical research. It is used to detect and quantify proteins contained in the tested sample, such as antibodies or protein antigens. The method is based on the formation of bonds between the antigen and the antibody, which is demonstrated by a colour reaction, which takes place thanks to enzymes conjugated with immunoglobulins and their appropriate substrates.

5. The HET-CAM (hen's egg-chorioallantoic membrane test), used in the study by $\mathrm{Al}$ et al., ${ }^{7}$ is a sensitive assay for the assessment of the toxicity of chemicals, including the toxicity to the oral mucosa. ${ }^{34}$ komórki oraz cytotoksyczności nowych leków. Test MTT wykorzystuje zdolność enzymu - dehydrogenazy mitochondrialnej do przekształcania rozpuszczalnej w wodzie soli tetrazolowej (bromek 3-(4,5-dimetylotiazol-2-yl)- 2,5-difenylotetrazoliowy) do nierozpuszczalnego formazanu. Po rozpuszczeniu kryształów formazanu w dimetylosulfotlenku lub izopropanolu, powstaje barwny roztwór, którego intensywność zabarwienia mierzona jest spektrofotometrycznie w zakresie długości fal 492-570 nm. Ilość barwnego zredukowanego MTT jest proporcjonalna do aktywności oksydacyjnej mitochondriów komórki, a w ściśle określonych warunkach doświadczalnych do liczby żywych komórek w populacji. Jednak zgodnie z nowymi badaniami, test ten może okazać się niewłaściwym do oceny liczby żywych komórek, co może również wpływać na interpretację wyników. ${ }^{32}$

2. Test XTT wykorzystano w jednym badaniu. ${ }^{30}$ Test ten podobnie jak MTT wykrywa metabolizm mitochondrialny, jednak jest on czulszy w stosunku do testu MTT. ${ }^{30}$

3. Test cytometrii przepływowej (FCM) polegający na retencji barwników posłużył w jednym $z$ badań ${ }^{31}$ do analizy liczby żywych oraz apoptycznych i nekrotycznych komórek. ${ }^{33}$

4. Test Elisa (enzyme-linked immunosorbent assay - test immunoenzymatyczny) użyty w jednym $\mathrm{z}$ badań wykorzystano celem oceny poziomu uwalnianej IL-6 oraz bFGF. ${ }^{30}$ Jest to jeden $\mathrm{z}$ najpopularniejszych testów stosowanych w badaniach medycznych. Służy do wykrywania i ilościowego oznaczania białek zawartych w badanej próbce, takich jak np. przeciwciała czy antygeny o charakterze białkowym. Działanie metody opiera się na tworzeniu wiązań pomiędzy antygenem a przeciwciałem, które uwidacznia reakcja barwna, zachodząca dzięki skoniugowanym z immunoglobulinami enzymom i odpowiednich dla nich substratom. 
6. The confocal laser scanning microscope was used by researchers in one of the studies. ${ }^{8}$ It is an invaluable tool for conducting a wide range of medical analyses. It enables the formation of thin optical sections of specimens, precise observation of the structure of the tested sample, and creation of three-dimensional image reconstructions. ${ }^{35}$

Based on the results of the aforementioned studies, it was also possible to conclude that dental adhesives, due to their cytotoxic effect, lead to various types of cell death: apoptosis and necrosis, and as a result, to lysis, or cell disintegration and the release of its contents to the oral environment. ${ }^{36}$

However, it is necessary to distinguish between these two types of cell death due to their different course. Apoptosis is programmed cell death, which is a physiological process that determines the proper functioning of the body, always following a specific pattern. It is a very important process for the body because it leads to the removal of redundant, harmful or damaged cells. ${ }^{37,38}$ On the other hand, necrosis is a passive, spontaneous and pathological process. It occurs as a result of physical, chemical and biological factors. ${ }^{37-39}$

It can, therefore, be concluded that the cases of apoptosis and necrosis identified in the research are initiated by the cytotoxic effect of the components of dental adhesives, and should not occur in the case of using biocompatible medical products.

\section{Conclusion}

Research shows that dental adhesives have a cytotoxic effect on fibroblasts of the oral mucosa, although to a different degree. Their concentration and the time of contact with the mucosa are very important, which is extremely difficult to control in the case of geriatric patients. Moreover, these materials have a negative overall effect on the health of
5. Test HET-CAM (hen's egg-chorioallantoic membrane test) zastosowany $\mathrm{w}$ badaniach $A l^{\prime} a$ i wsp. ${ }^{7}$ to czuły test do oceny toksyczności substancji chemicznych między innymi na błonę śluzową jamy ustnej. ${ }^{34}$

6. Skanujący laserowy mikroskop konfokalny posłużył badaczom w jednym z badań. ${ }^{8}$ Jest nieocenionym narzędziem do prowadzenia szerokiego zakresu analiz medycznych. Umożliwia tworzenie cienkich przekrojów optycznych preparatów, dokładną obserwację struktury badanej próbki oraz tworzenie trójwymiarowych rekonstrukcji obrazu. ${ }^{35}$

Na podstawie wyników analizowanych badań można było również stwierdzić, że kleje stomatologiczne poprzez swój efekt cytotoksyczny doprowadzają do różnego typu śmierci komórek: apoptozy i nekrozy, a w efekcie do lizy czyli rozpadu komórki i uwolnieniu jej zwartości do otoczenia. ${ }^{36}$

Należy jednak rozróżnić te dwa typy śmierci komórek, ze względu na odmienny przebieg. Apoptoza jest zaprogramowaną śmiercią komórki, będącą procesem fizjologicznym warunkującym prawidłowe funkcjonowanie organizmu, przebiegającym zawsze według określonego schematu. Jest ona dla organizmu procesem bardzo ważnym, gdyż prowadzi do usunięcia komórek zbytecznych, szkodliwych czy uszkodzonych. ${ }^{37,38}$ Nekroza natomiast jest procesem biernym, spontanicznym i patologicznym. Zachodzi pod wpływem czynników fizycznych, chemicznych i biologicznych. ${ }^{37-39}$ Można zatem stwierdzić, że wykryte w badaniach przypadki apoptozy i nekrozy są zainicjowane cytotoksycznym działaniem składników klejów stomatologicznych i nie powinny mieć miejsca w przypadku stosowania biokompatybilnych produktów medycznych.

\section{Podsumowanie}

Badania eksperymentalne dowodzą, że preparaty adhezyjne w różnym stopniu, wywołują 
their users. Therefore, it is necessary to educate patients with dentures and prevent the misuse of commonly available adhesive materials, reserving them only for situations when their use is absolutely necessary. efekt cytotoksyczny w stosunku do komórek błony śluzowej jamy ustnej. Bardzo ważne jest ich stężenie oraz czas kontaktu $\mathrm{z}$ błoną śluzową, co jest niezwykle trudne w kontroli pacjentów geriatrycznych. Ponadto, materiały te mają negatywny ogólny wpływ na zdrowie ich użytkowników. W związku z tym konieczna jest edukacja pacjentów protetycznych i zapobieganie nadużywaniu powszechnie dostępnych materiałów adhezyjnych, rekomendując je jedynie w przypadkach bezwzględnie koniecznych.

\section{References / Piśmiennictwo}

1. Chen $F$, Wu T, Cheng $X$ : Cytotoxic effects of denture adhesives on primary human oral keratinocytes, fibroblasts and permament L929 cell lines. Gerodontology 2012; 1: 4-10.

2. Oliveira da Rosa WL, Simone Oliveira GD, Rosa CH, Fernandes da Silva A, Lund RG, Piva E: Current trends and future perspectives in the development of denture adhesives: an overview based on technological monitoring process and systematic review. J Biomedical Sci 2015; 4: 1-7.

3. Papadiochou S, Emmanouil I, Papadiochos $I$ : Denture adhesives: a systematic review. J Prosthet Dent 2015; 113: 391-397.

4. Koronis S, Pizatos E, Polyzois G, Lagouvardos $P$ : Clinical evaluation of three denture cushion adhesives by complete denture wearers. Gerodontology 2012; 29: 161-169.

5. Jain P, Sikka R, Arora D, Khatri M: Denture adhesives from then till now. J Dental Herald 2015; 001-003.

6. Fallahi A, Khadivi $N$, Roohpour $N$, Middleton AM, Kazemzadeh-Narbat $M$, Annabi N, Khademhosseini A, Tamayol A: Characterization, mechanistic analysis and improving the properties of denture adhesives. Dent Mater 2018; 34: 120-131.
7. Al RH, Dahl JE, Morisbak E, Polyzois GL: Irritation and cytotoxic potential of denture adhesives. Gerodontology 2005; 22: 177-183.

8. De Gomes PS, Fugueiral MH, Fernandes MHR, Scully C: Cytotoxicity of denture adhesives. Clin Oral Investig 2011; 15: 885-893.

9. Prasad $R$, Hawthorne $B$, Dhamaraj D, McDowell I: Zinc in denture adhesives: a rare cause of copper deficiency in patient on home parenteral nutrition. BMJ Case Rep 2015: bcr2015211390.

10. Coates AJ: Usage of denture adhesives. J Dent 2000; 28: 137-140.

11. ISO 10873.2010. Dentistry - Denture adhesives.

12. Yegin E, Akpinar YZ, Yuvuz T, Aslan MA: Effect of different denture adhesives on retention of complete dentures: an in vivo study. J Adhesion Science and Technology 2017; 31(18): 2044-2052.

13. López-García S, Pecci-Lloret MP, GarcíaBernal D, Guerrero-Gironés J, Pecci-Lloret MR, Rodríguez-Lozano FJ: Are Denture Adhesives Safe for Oral Cells? J Prosthodont 2020; doi: 10.1111/jopr.13226.

14. Yamada M, Takase K, Suehiro F, Nishimura $M$, Murata $H$ : Effects of denture adhesives and mouth moisturizers to human oral fibro- 
blast and human keratinocyte cells using direct and indirect cel culture systems. Dent Mater J 2020; 39(4): 571-576.

15. Kumar MS, Thombare RU: A compertaive analysis of the effect of various denture adhesives available in market on the retentive ability of the maxillary denture: an in vivo study. J Indian Prosthodont Soc 2011; 11(2): 82-88.

16. Bogucki ZA: Denture adhesives' effect on retention of prostheses in patients with xerostomia. Adv Clin Exp Med 2018; 27(9): 12471252.

17. Bogucki ZA: Clinical aspects of the use of dental adhesive materials in patients with chronic xerostomia. Gerodontology 2013; 30(2): 162166.

18. Gruca O, Janas D, Kubica A, Masny M, Mospan I, Pluciński M, Kasperski J: Wpływ górnej protezy całkowitej i środków adhezyjnych na odczuwanie smaku. Dent Forum 2015; 43: 57-62.

19. Borole A, Roopa KT, Khandelwal PV: A comperative evaluation of the effects of different commercially available denture adhesives on the growth of Candida species in diabetic and nondiabetic subjects: an in vivo study. J Dent Allied Scienc 2016; 5(2): 63-69.

20. Górska R, Nowak M: Wybrane zagadnienia z diagnostyki i leczenia chorób błony śluzowej jamy ustnej. F Pol Otorhino 2017; 6(2): 1422.

21. Knychalska-Karwan Z: Fizjologia i patologia błony śluzowej jamy ustnej. Wyd. Czelej 2009; s. 15.

22. Kmieć Z: Histologia i cytofizjologia zęba i jamy ustnej. Wyd. Elsevier 2007; s. 118.

23. Sawicki W, Malejczyk J: Histologia. Wyd. PZWL 2012; s. 157-159.

24. Lee $H G$, Eun $H C$ : Differences between fibroblasts cultured from oral mucosa and normal skin: implication to wound healing. J Dermatol Sci 1999; 21(3): 176-182.

25. Sloan P: Current concepts of the role of fibroblasts and extracellular matrix in wound he- aling and their relevance to oral implantology. J Dent 1991; 19: 107-109.

26. McKeown STW, Barnes JJ, Hyland PL. Lundy FT, Fray MJ, Irwin CR: Matrix Metalloproteinase-3 differences in oral and skin fibroblasts. J Dent Res 2007; 86(5): 457462.

27. Szpaderska AM, Zuckerman JD, DiPietro LA. Differental injury responses in oral mucosal and cutaneous wounds. J Dent Res 2003; 82(8): 621-626.

28. Wiśniewska-Okupniak E, Szyfter W. Diagnostyka zapaleń jamy ustnej $\mathrm{z}$ nadżerkami i owrzodzeniami błony śluzowej. Pol Otorhino Rev 2015; 4(1): 15-19.

29. Wierzchowski K, Pacyno K, Pilarek $M$. Hodowla wgłębna adherentnych fibroblastów linii L929 na mikronośnikach sferycznych w warunkach mieszania typu wave. Acta Sci Pol Biotechnol 2018; 17(2): 59-68.

30. Soares ASLS, Scelza MZ, Spoladore J, Gallito $M A$, Oliveira F, Morales RCM, Alves GG: Comparison of primary human gingival fibroblasts from an older and a young donor on the evaluation of cytotoxicity of denture adhesives. J Appl Oral Sci 2018; 26:e20160594.

31. Lee Y, Ahn JS, Yi YA, Chung SH, Yoo YJ, Ju $S W$, Hwang JY, Seo DG: Cytotoxicity of four denture adhesives on human gingival fibroblasts cells. Acta Odontol Scand 2015; 73(2): 87-92.

32. Jaszczyszyn A, Gaqsiorowski K. Limitations of the MTT Assay in Cell Viability Testing. Adv Clin Exp Med 2008; 17(5): 525-529.

33. Vermes I, Haanen $C$, Reutelingsperger $C$ : Flow cytometry of apoptotic cell death. J Immunol Methods 2000; 243(1-2): 167-190.

34. Luepke NP, Kemper FH: The het-cam test: an alternative to the draize eye test. Fd Chem. Toxic 1986; 24 (6/7): 495-496.

35. Korczyński J: Nowy wymiar mikroskopii skanujący laserowy mikroskop konfokalny. Kosmos 2013; 62(2): 149-160.

36. Maruniewicz M, Wojtaszek P: Pochodzenie i 
ewolucja śmierci komórki. Postępy Biol Kom 2007; 34(4): 651-667.

37. Stępień A, Izdebska M, Grzanka A: Rodzaje śmierci komórki. Postepy Hig Med Dosw 2007; 61: 420-428.

38. Hordyjewska A, Pasternak K: Apoptyczna śmierć komórki. Adv Clin Exp Med 2005; 14(3): 545-554.
39. Paduch R, Klatka M, Klatka J: Rodzaje śmierci komórki. Pom J Life Sci 2015; 61(4): 411418.

Zaakceptowano do druku: 16.02.2021 r.

Adres autorów: 15-276 Białystok,

ul. M. Skłodowskiej-Curie 24A.

(C) Zarząd Główny PTS 2021. 